\title{
Determinants Associated with Discontinuation of Modern Contraceptive in East Kalimantan: a Further Analysis of Indonesia Demographic and Health Survey 2017
}

\author{
Ike Anggraeni, ${ }^{1}$ Annisa Nurrachmawati, ${ }^{1}$ Winardi, ${ }^{2}$ Hasmawati, ${ }^{1}$ \\ Dewi Endah Ramadhani ${ }^{2}$ \\ ${ }^{1}$ Department of Biostatistics and Health Reproduction, Faculty of Public Health, Universitas Mulawarman, \\ Samarinda, Indonesia, ${ }^{2}$ National Population and Family Planning Board \\ East Kalimantan Representative, Samarinda, Indonesia
}

\begin{abstract}
The national family planning program in East Kalimantan needs to achieve a larger target on modern contraceptives. Despite the fertility decline, this program still facing increasing discontinuation rates. A better understanding of the factors behind the discontinuation of a modern method would help in improving programs. This study aims to analyze the determinants of discontinuation of modern contraceptive use. This was a cross-sectional study, the dataset came from Indonesia Demographic and Health Survey 2017 of East Kalimantan Province. The sample is all couples of childbearing age between 10-49 years with marital status who have used and are still using contraception (408 samples). Descriptive analyses were used to assess the reasons for discontinuation. Multiple logistic regression was used to estimate the likelihood of discontinuation by demographic characteristics and others. The proportion of respondents who continue using modern contraceptives was $51 \%$, against $49 \%$ discontinuation. The reasons for discontinuation were the husband's disapproval (31\%) and health problems related to side effects (26.5\%). In the multivariate analysis showed maternal age, women who live in urban areas and women with birth planning near the future will have an opportunity to discontinue in modern contraceptives. It concluded that there is still high modern contraceptive discontinuation in East Kalimantan, therefore it needed for disseminating information through entertainment-education in social media, health workers better counseling services from also better tools, and include the male participation in family planning counseling.
\end{abstract}

Key words: Family planning, fertility, modern contraceptive discontinuation

\section{Determinan yang Berhubungan dengan Putus Pakai Kontrasepsi Modern di Kalimantan Timur: Analisis Lanjut Survei Demografi dan Kesehatan Indonesia 2017}

\begin{abstract}
Abstrak
Program keluarga berencana nasional di Kalimantan Timur perlu mencapai target yang lebih baik dalam penggunaan kontrasepsi modern. Meskipun terdapat penurunan fertilitas, namun program keluarga berencana masih menghadapi peningkatan angka putus pakai. Pemahaman yang lebih baik tentang faktor-faktor di balik putus pakai metode kontrasepsi modern akan membantu meningkatkan program. Penelitian ini bertujuan menganalisis faktor-faktor penentu putus pakai penggunaan kontrasepsi modern. Desain penelitian ini adalah cross-sectional, set data berasal dari Survei Demografi Kesehatan Indonesia 2017 untuk Provinsi Kalimantan Timur. Sampel adalah semua pasangan usia subur berusia 10-49 tahun dengan status perkawinan baik bagi yang pernah menggunakan dan masih menggunakan kontrasepsi, yaitu 408 sampel. Analisis deskriptif digunakan untuk menilai alasan putus pakai. Regresi logistik berganda digunakan untuk memperkirakan kemungkinan putus pakai berdasar atas karakteristik demografis dan lainnya. Proporsi responden yang masih terus menggunakan kontrasepsi modern adalah $51 \%$ dibanding dengan $49 \%$ putus pakai. Alasan penghentian adalah ketidaksetujuan suami (31\%) dan masalah kesehatan yang berkaitan dengan efek samping (26,5\%). Analisis multivariat menunjukkan usia ibu, wanita yang tinggal di daerah perkotaan, dan wanita dengan perencanaan kelahiran dalam waktu dekat akan memiliki kesempatan untuk berhenti menggunakan kontrasepsi modern. Dapat disimpulkan bahwa kejadian putus pakai kontrasepsi modern masih tinggi di Kalimantan Timur, oleh karena itu diperlukan diseminasi informasi melalui entertainment-education dalam sosial media, layanan konseling dari petugas kesehatan, serta alat bantu konseling yang lebih baik dan juga keikutsertaan pria dalam proses konseling.
\end{abstract}

Kata kunci: Fertilitas, keluarga berencana, putus pakai kontrasepsi modern

Received: 16 December 2019; Revised: 22 April 2020; Accepted: 23 April 2020; Published: 31 August 2020

Correspondence: Ike Anggraeni. Department of Biostatistics and Health Reproduction, Faculty of Public Health, Universitas Mulawarman. Jln. Sambaliung Kampus Unmul Gunung Kelua, Samarinda 75123, East Kalimantan, Indonesia. E-mail: ikeanggraeni@ fkm.unmul.ac.id 


\section{Introduction}

Family planning intervention believed had contributed to birth rates and mortality rate reduction, which led to decline in population growth rates, especially in developing countries. Indonesia as one of a country with high use of contraception and low fertility. ${ }^{1}$ Data from Indonesia Demographic and Health Survey (IDHS) showed the total fertility rate (TFR) has decreased by 0.2 points, from 2.6 per woman of childbearing age to 2.4 per woman. ${ }^{2,3}$ These showed the progress achieved by the family planning program in the past 5 years and its contribution to the demographic transition situation in Indonesia. However, Indonesia still deals with the high dropout of modern contraception, which increase $27 \%$ in 2012 to $34 \%$ in $2017 .^{3}$

Some studies revealed that there are several factors influenced contraceptive dropout such as age, level of education and side effect of contraceptive use..$^{4-6}$ Another study shows that the factors that most determine the incidence of contraception discontinuation are the wife's age, number of children and the composition of children after controlled by husband \& wife education factors, living area, household expenditure per capita, history of wife menstruation, husband and wife health knowledge. ${ }^{7}$

The IDHS 2012 results show that the highest number of family planning discontinuation was in pill contraceptive users (40.7\%) followed by injection (24.7\%). ${ }^{2}$ The magnitude of short-term contraceptive use generally impacts the high rate of discontinuation of injecting contraceptives, implants and IUDs showing a drop-out rate above $20 \%$ during the first 12 months due to side effects. Side effects can cause women stop using certain types of contraception or switch to use other types of contraception methods. ${ }^{8}$ Study of Yideta et al. ${ }^{9}$ showed that contraceptive discontinuation was found to be highest for the contraceptive pills (30.0\%). Agrahari et al. ${ }^{10}$ stated methods that require active user involvement and compliance to be used properly such as pills, are more likely to be discontinued. Meanwhile, long acting method showed less discontinuation as was observed among users of the implant in Modey et al. ${ }^{11}$

Many factors related to the discontinuation of contraception and these were specific in each community. It is important to identify these factors, in order to provide a basis for developing policies and programs that are more effective in overcoming barriers to the use of family planning.

This study aimed to analyze determinant (demography, parity, wealth index and fertility preference with discontinuation) related to modern contraceptive discontinuation in East Kalimantan.

\section{Methods}

The study analyzed data derived from the IDHS 2017 of East Kalimantan Province. The IDHS represents households and women of reproductive age (i.e., 15-49 years) based on stratified multi-stage sampling technique. ${ }^{3} \mathrm{~A}$ cross-sectional design was used in this study to determine the effect of demographic factors, parity factors, wealth index factors and fertility preference factors on the discontinuation using of modern contraceptives.

The analysis unit was all female respondents (1,221 women) of childbearing age (15-49 years), who had a history of family planning use within the 5 years before the survey. The dependent variable in this study was the modern family planning discontinuity, which obtained from several questions about contraception. The first question, the respondent asked was: "Do you use methods to prevent pregnancy now (Q303)?” If the answer "Yes" then respondent asked about type of method used (Q304). Further, they asked deeply about family planning methods that were returned in the last 5 years, if the respondent answered that they did not use contraception methods since 2012, then it was coded into missing data.

As many as 462 women using contraception methods for the last 5 years consisted of 408 modern, 52 traditional, and 759 who did not use family planning at that time. Since research focuses on the types of modern family planning methods, the number of samples taken were 408 respondents.

Respondents classified as discontinued using modern contraceptive, if they currently not using or using traditional methods and the previous (the last 5 years) using a modern contraceptive method. Respondents classified as continue using a modern family planning, if for 5 years until now use any of modern contraceptive.

Independent variables obtained from several questions, that is respondent age (Q106), residence (Q102), education (Q108), parity 
(Q314A), wealth index (Q HWLTHI), working status (Q909), fertility preferences (Q803), and the desire to add children (Q804), sourced from the Standard Recode Manual for DHS-7. ${ }^{12}$

Descriptive analyses carried out to provide information on each possible determinant. Bivariate analysis, used to determine the relationship between independent variables on the dependent variable. Multiple logistic regression analyses conducted to determine determinants that influence women's discontinuation decision in modern contraceptives.

\section{Results}

Respondent characteristic's distribution based on demographic factors, parity and wealth index can be seen in Table 1 . Table 1 showed that most of the respondents were around 30-34 years (25.7\%) and majority resided in urban areas (74.3\%).

\section{Table 1 Respondent Characteristic}

\begin{tabular}{|c|c|c|}
\hline Variables & $n=408$ & $\%$ \\
\hline \multicolumn{3}{|l|}{ Age (years) } \\
\hline $15^{-19}$ & 6 & 1.5 \\
\hline $20-24$ & 38 & 9.3 \\
\hline $25^{-29}$ & 78 & 19.1 \\
\hline $30-34$ & 105 & $25 \cdot 7$ \\
\hline $35-39$ & 81 & 19.9 \\
\hline $40-44$ & 69 & 16.9 \\
\hline $45-49$ & 31 & 7.6 \\
\hline \multicolumn{3}{|l|}{ Residence } \\
\hline Urban & 303 & $74 \cdot 3$ \\
\hline Rural & 105 & $25 \cdot 7$ \\
\hline \multicolumn{3}{|l|}{ Education } \\
\hline Primary & 122 & 29.9 \\
\hline Secondary & 252 & 61.8 \\
\hline Higher & 34 & 8.3 \\
\hline \multicolumn{3}{|l|}{ Occupation } \\
\hline Work & 208 & 51.0 \\
\hline Not work & 200 & 49.0 \\
\hline \multicolumn{3}{|l|}{ Literacy } \\
\hline Cannot read at all & 5 & 1.2 \\
\hline Can only read sentence part & 7 & 1.7 \\
\hline Can read entire sentence & 396 & 97.1 \\
\hline \multicolumn{3}{|l|}{ Wealth index } \\
\hline Lowest & 54 & 13.2 \\
\hline Second & 98 & 24.0 \\
\hline Middle & 95 & $23 \cdot 3$ \\
\hline Fourth & 79 & 19.4 \\
\hline Highest & 82 & 20.1 \\
\hline
\end{tabular}

More than half of the respondents complete a secondary education (61.8\%). The employment status of respondents was not much different, $51 \%$ who work and $49.0 \%$ who do not work. Almost all respondents were able to read all sentences well (97.1\%) and $24.0 \%$ of respondents were in the lower middle wealth index, $23.3 \%$ were included in the middle, and $13.2 \%$ respondents had the lowest wealth index.

Table 2 provides information, the highest number of children born was around 1-2 children (55.9\%). Out of 408 respondents, $55.9 \%$ used modern methods and $7.8 \%$ used traditional methods, and $36.3 \%$ remained did not use any.

Among respondents who used modern contraception methods, most respondents used pill (19.9\%) and 3 months injectable (17.4\%), and the least used type of contraception was vasectomy (0.2\%), tubectomy (1\%) and implants (3.2\%). The proportion of respondents who discontinue using modern contraceptive was $49 \%$ with the most common reason, because, their husband's disapproval (31\%) and health problems (26.55\%) and most of last method discontinued were short-acting contraceptive methods like injection (51.0\%) and pills (41.0\%).

The fertility preference factor regarding the ideal number of children desired by both partners was 2 children (50.5\%) and more than half of the respondents $(62.0 \%)$ stated that they did not want to have more children. However 58.3\% respondents answered did not have planning for pregnancy.

Result analyses showed that of the 8 risk factors, there was only 1 factor, wealth index was found not significant with modern contraceptive discontinuation. While 7 other determinants such age, residence, education, employment, parity, ideal number of children, birth planning and desire to add children ( $\mathrm{p}$ value $<0.05$ ) had an association with the modern contraceptive discontinuation.

From the entire analysis process that has been carried out it can be concluded that, of the 7 variables thought to be related to modern contraceptive discontinuation, apparently there were only 3 variables that were significantly related to the modern contraceptive discontinuation.

The results of the analysis, obtained the value of $\operatorname{Exp}(\mathrm{B})$ of age was 1.098 (95\%CI: 1.05-1.13). It indicates that every 1 year increase in maternal age has a tendency discontinuation modern contraceptive by 1.098 times. The $\operatorname{Exp}(\mathrm{B})$ of 
Table 2 Characteristics of the Respondents based on Fertility Determinant

\begin{tabular}{|c|c|c|}
\hline Variables & $n=408$ & Percentage \\
\hline \multicolumn{3}{|l|}{ Parity } \\
\hline o & 6 & 1.5 \\
\hline $1-2$ & 228 & 55.9 \\
\hline$\geq 3$ & 174 & 42.6 \\
\hline \multicolumn{3}{|l|}{ Type of contraceptive method } \\
\hline Not using & 148 & 36.3 \\
\hline Traditional & 32 & 7.8 \\
\hline Modern & 228 & 55.9 \\
\hline \multicolumn{3}{|c|}{ Current use of a modern contraceptive method $(n=228)$} \\
\hline Pill & 81 & 19.9 \\
\hline IUD/intrauterine devices & 16 & 3.9 \\
\hline 1-month injectable & 27 & 6.6 \\
\hline 3-month injectable & 71 & 17.4 \\
\hline Condom & 15 & 3.7 \\
\hline Implant & 13 & 3.2 \\
\hline Tubectomy & 4 & 1.0 \\
\hline Vasectomy & 1 & 0.2 \\
\hline \multicolumn{3}{|l|}{ Discontinuation of family planning } \\
\hline Continue of contraceptive & 208 & 51.0 \\
\hline Discontinue of modern contraceptive & 200 & 49.0 \\
\hline \multicolumn{3}{|c|}{ Reason of discontinuation of modern contraceptive $(n=200)$} \\
\hline Want to get pregnant & 9 & 4.5 \\
\hline Husband disapproval & 62 & 31.0 \\
\hline Fear of side effects & 2 & 1.0 \\
\hline Health problems & 53 & 26.5 \\
\hline Access/availability & 15 & 7.5 \\
\hline Want more an effective method & 2 & 1.0 \\
\hline Not comfortable to use & 5 & 2.5 \\
\hline Rarely had sex & 2 & 1.0 \\
\hline Finance & 11 & 5.5 \\
\hline No reason & 3 & 1.5 \\
\hline Menopause & 4 & 2.0 \\
\hline Divorce & 6 & 3.0 \\
\hline Forced the IUD out & 18 & 9.0 \\
\hline Others & 1 & 0.5 \\
\hline Do not know & 7 & 3.5 \\
\hline \multicolumn{3}{|c|}{ Last method discontinued in last 5 years $(\mathrm{n}=200)$} \\
\hline Pill & 82 & 41.0 \\
\hline Injection & 102 & 51.0 \\
\hline Implants/norplants/IUD & 16 & 8.0 \\
\hline \multicolumn{3}{|l|}{ Fertility preferences desire more children } \\
\hline Want to have more children & 155 & 38.0 \\
\hline Do not want to have more children & 253 & 62.0 \\
\hline \multicolumn{3}{|l|}{ Ideal number of children } \\
\hline o & 5 & 1.2 \\
\hline 1 & 11 & 2.7 \\
\hline 2 & 206 & 50.5 \\
\hline 3 & 74 & 18.1 \\
\hline 4 & 54 & 13.2 \\
\hline 5 & 18 & 4.4 \\
\hline $6+$ & 6 & 1.5 \\
\hline Not know & 34 & 8.3 \\
\hline \multicolumn{3}{|l|}{ Birth planning in future } \\
\hline Wanted immediately & 51 & 12.5 \\
\hline Wanted later & 119 & 29.2 \\
\hline Not decided/do not know & 238 & 58.3 \\
\hline
\end{tabular}


Table 3 Relation between Demography, Parity, Wealth Index and Fertility Preference with Discontinuation of Modern Contraceptive

\begin{tabular}{lc}
\hline Variables & p Value \\
\hline Age & $<0.001^{* * * *}$ \\
Residence & $<0.001^{* * *}$ \\
Education & $0.008^{* * *}$ \\
Occupation & $0.005^{* * *}$ \\
Parity & $0.011^{*}$ \\
Wealth index & 0.66 \\
Fertility preference & \\
Birth planning in the future & $<0.001^{* * *}$ \\
Desire of more kids & $0.0088^{* *}$ \\
\hline
\end{tabular}

Note: "significant in p value $<0.05,{ }^{* *}$ significant in $\mathrm{p}<0.01$, *** significant in $\mathrm{p}<0.001$

residence was 2.009 have meant that women who live in urban areas will have the opportunity to discontinue using modern contraceptive by 2.009 times compared to women who live in rural areas. While the birth planning factor (1) with $\operatorname{Exp}(B)$ value of 2.636, means that women who desired birth planning later has a tendency discontinue using modern contraceptive by 2.636 times compared to mothers who do not have birth planning, on the other hand women who plan immediate birth, have a tendency to discontinue using modern contraceptive by 14.101 times compared to mothers who do not have birth planning.

The Nagelkerke's $\mathrm{R}^{2}$ value described in Table 4 shows the value of 0.201 which means that the regression model obtained can explain $20.1 \%$ of modern contraceptive discontinuation variations and $79.9 \%$ could explained by variables outside the study. While the value of Hosmer and Lemeshow test (>0.05) which means that the model has sufficiently explained the data goodness of fit.

\section{Discussion}

Contraceptive method choice in East Kalimantan was similar to national level. Most of women adopted reversible method like pills (19.9\%), injectable (17.4\%), IUD (3.9\%) while vasectomy was less common (0.2\%). The discontinuation of modern contraceptive methods occurred more on women who use short-acting methods that could be easily discontinued, such as injections, pills and condoms compared to long term methods such as the implants and intrauterine devices (IUD). This is similar with the study of BardenO'Fallon et al. ${ }^{13}$ which found that implants was the lowest (6.3\%) while condoms was the highest discontinuation rate (62.9\%). Some study had proven that discontinuation of contraception often leads to unintended pregnancies, ${ }^{14-16}$ reduces the impact of family planning programs, and contributes to poor reproductive health indicators for women and high. ${ }^{17}$ These reasons what made the problem of contraceptive discontinuation important to overcome.

Multivariate analysis showed there were three significant variables related to the discontinuation of contraceptive modern use, that is maternal age with value of $\operatorname{Exp}(\mathrm{B}): 1.098$ (95\%CI: 1.05-1.13), urban residence $(\operatorname{Exp}(B): 2.009)$, and planning for pregnancy $(\operatorname{Exp}(B): 14.101)$. Young women, according to study in Kenya tends to have good knowledge and awareness of contraception, but still had a barrier in terms of myths and misconceptions and also the influence of social network approval on the use of family planning, beyond the individual's beliefs..$^{18}$ In that settings, mass and peer campaign strategies needed for family planning program so it could engage with the wider community.

In line with study of Safari et al. ${ }^{19}$ and Ariffuddin et al. ${ }^{20}$ which stated that there was a

Table 4 Final Model of Logistic Regression Result

\begin{tabular}{lcccc}
\hline Variables & p Value & B & Exp(B) & 95\%CI \\
\hline Age & $<0.001$ & 0.094 & 1.098 & $1.05-1.13$ \\
Residence & 0.005 & 0.697 & 2.009 & $1.23-3.28$ \\
Birth planning in the future & $<0.001$ & & & \\
$\quad$ Birth planning (1) & 0.001 & 0.949 & 2.636 & $1.49-4.47$ \\
$\quad$ Birth planning (2) & $<0.001$ & 2.617 & 14.101 & $5.77-33.7$ \\
Nagelkerke's R ${ }^{2}$ & \multicolumn{3}{c}{0.201} \\
Hosmer and lemeshow test & \multicolumn{3}{c}{0.355} \\
\hline
\end{tabular}


correlation of maternal age with discontinuation of modern contraception. The aging period of 2035 years is time for birth spacing period, to meet that contraception with long duration (2-4 years) and reversible is needed. Meanwhile, for women over 35 years old, it is the phase to limit births, long term contraceptive was more appropriate.

This study also found that $12.5 \%$ respondent still have the desire to have more children in the near future, and in the multivariate analysis showed this associate with discontinuation. Its similar with study of Bakibinga et al. ${ }^{21}$ also showed that women who wanted more children had higher opportunity to have contraceptive discontinuation compared to women wanted no more children.

Desire for more children made women choose the short term contraceptive method such pills and injections, which easily self-discontinuation. Study of Curtis ${ }^{15}$ stated that pill and condoms are predominate in the mix of reversible methods in Brazil tending to lead to high discontinuation rate among reversible method. In the meantime, other studies in Bangladesh and Ethiopia found that fertility preference to space or to limit births, was associated with contraceptive discontinuation.9,22

Another possible explanation about how fertility preference affected discontinuation is ambivalence about contraceptive use and about pregnancy intentions co-exist. The increase of desire to had more than two children will increase the likelihood of women abandoned their use of modern contraceptive. Study of Khalil et al. ${ }^{23}$ showed that the proportion of individuals who stated that they planned to use family planning in the future decreased from $80 \%$ among women with one child to $41 \%$ among women with four or more children.

More complicated with $31 \%$ husband disapproval of contraceptive use, this will lead women to use traditional methods or not use modern contraceptive at all. Study of Osei et al. ${ }^{24}$ stated that women in supportive relationships are more likely than those in unsupportive relationships to continue use of modern contraceptives. The result of study in India and Ethiopia also found that women having support from the husband for contraceptive use were less likely to discontinue the method. ${ }^{25,26}$ This may lead to suggest that family planning field workers should continue to give information and motivate woman also their husband to improve beliefs and attitudes so they would continue using a modern especially long-acting modern contraceptive as the most effective and reliable method for their childbearing plan.

In order to prevent a health problem or complain after using modern contraceptive methods, a better and effective counseling from midwife and other health workers about types of contraceptive information, benefit and side effect should be given. A systematic review found that interventions targeting women, initiating a method (including structured counseling on side effects) tended to show positive effects on contraceptive continuation. ${ }^{27}$

A decision making tool in choosing a contraceptive method had been launched by National Family Planning Coordinating Agency to support health workers in counseling, but according to the latest study in Yogyakarta, the utilization of the tool was still low and the use of assistivedeviceshasnotbeen effectiveinincreasing the use of long-term contraception methods. ${ }^{28}$ In order to optimize the tool utilization, National Family Planning Coordinating Agency should review or improved these tools to overcome the obstacles encountered.

The study also found that women in urban areas were found to be associated with higher risk of contraceptive discontinuation, which could be caused by better access to family planning information and services that allows women to discontinue contraception in order to find a better method for them. Similar to the study, the result of study in Haiti revealed that the availability of contraceptive options in urban areas would also impact women's contraceptive use choices and determines the method mix among the users. ${ }^{29}$ Therefore, it's necessary to increase the demand for modern contraceptive, though strengthens adequate information using the most appropriate mass media that accessible for women in urban setting.

A meta-analysis found that campaign format that included an entertainment-education component were positively related to family planning behaviors for women compared to mass media campaign that used only a traditional advertising format. ${ }^{30}$ A longitudinal study in Nigeria proved that entertainment-education intervention in urban area with 30 minute radio magazine with various magazine elements, such as listener interviews and call-in "ask the expert", could increase modern contraceptives used between 2.3 to $15.5 \%$ in each city. ${ }^{31}$ With 
the current advancement of social media, most informative social media could be used as an option of modern contraceptive family planning campaign with a wider range of target. Some studies had proven that social media effective for disseminating information targeting young and productive ages (18-44 years)..$^{32,33}$

The finding of this study implies that the high percentage of modern contraceptive discontinuation still needs attention and overcome immediately. Maternal age, women who live in urban areas and women with birth planning near future will have an opportunity to discontinue in modern contraceptive. It indicated the importance of promoting a long-acting methods contraceptive through entertainmenteducation in social media. We also need to emphasize the role of family planning field workers; to motivate woman to continue using the modern contraceptive method. Some effort also needed for male involvement in family planning and their support in the modern contraceptive method, the couple counseling should be promoted in order to obtain belief and attitudes that impact on reducing discontinuation. National Family Planning Coordinating Agency should make a review and improvement of the current family planning decision making tools to strengthen the health workers' ability to provide better counseling.

\section{Conclusion}

It concluded that there is still high modern contraceptive discontinuation in East Kalimantan province, therefore it needed for disseminating information through entertainment-education in social media, health workers better counseling services from also better tools, and include the male participation in family planning counseling.

\section{Conflict of Interest}

There was no conflict of interest.

\section{Acknowledgments}

Theauthors would liketogivedeepestappreciation to all those who provided IDHS East Kalimantan Province data set in this study: National Family Planning and Coordination Agency; and Jakarta and National Family Planning and Coordination Agency, East Kalimantan Representatives.

\section{References}

1. Stover J, Winfrey W. The effects of family planning and other factors on fertility, abortion, miscarriage, and stillbirths in the spectrum model. BMC Public Health. 2017;17(Suppl 4):775.

2. Badan Pusat Statistik (BPS), Badan Kependudukan dan Keluarga Berencana Nasional (BKKBN), Kementerian Kesehatan (Kemenkes), ICF International. Survei demografi dan kesehatan Indonesia 2012. Jakarta: BPS, BKKBN, Kemenkes, ICF International; 2013.

3. Badan Kependudukan dan Keluarga Berencana Nasional (BKKBN), Badan Pusat Statistik (BPS), Kementerian Kesehatan (Kemenkes), ICF International. Survei demografi dan kesehatan Indonesia 2017. Jakarta: BKKBN, BPS, Kemenkes, ICF International; 2018.

4. Mufdlilah, Aryekti K. Factors causing contraceptive acceptors drop out. Kesmas Natl Public Health J. 2018;12(4):202-6.

5. Mahumud RA, Hossain MG, Sarker AR, Islam MN, Hossain MR, Khan JA. Prevalence and associated factors of contraceptive discontinuation and switching among Bangladeshi married women of reproductive age. Open Access J Contracept. 2015;6:13-9.

6. Anwar HM, Shazly E, Emara MAI, Abo RA, Agha A. Discontinuation of contraception in rural and urban areas in Menoufia Governorate. Menoufia Med J. 2016;29(4):996-9.

7. Indrawati L. Determinan kejadian berhenti pakai (drop out) kontrasepsi di Indonesia (analisa sekunder data Riskesdas 2010). Bul Penel Sistem Kes. 2014;17(1):55-62.

8. Ekoriano M, Novita F. Dinamika pemakaian kontrasepsi modern di indonesia (analisis data Susenas 2015). JKI. 2018;13(1):27-38.

9. Yideta ZS, Mekonen L, Seifu W, Shine S. Contraceptive discontinuation, method switching and associated factors among reproductive age women in Jimma town, Southwest Ethiopia, 2013. Fam Med Med Sci Res. 2017;6(1):1000213.

10. Agrahari K, Mohanty SK, Chauhan RK. Socio-economic differentials in contraceptive discontinuation in India. SAGE Open. 2016;6(2):2158244016646612.

11. Modey EJ, Aryeetey R, Adanu R. 
Contraceptive discontinuation and switching among Ghanaian women evidence from the Ghana demographic and health. Afr J Reprod Health. 2014;18(1):84-92.

12. United States Agency for International Development. Standard recode manual for DHS-7 [Internet]. Rockville, USA: United States Agency for International Development; 2018 [cited 2019 November 23]. Available from: https://dhsprogram.com/pubs/ pdf/DHSG4/Recode7_DHS_10Sep2018_ DHSG4.pdf.

13. Barden-O'Fallon J, Speizer IS, Calhoun LM, Corroon M. Women's contraceptive discontinuation and switching behavior in urban Senegal, 2010-2015. BMC Womens Health. 2018;18(1):35.

14. Curtis SL, Evens E, Sambisa W. Contraceptive discontinuation and unintended pregnancy: an imperfect relationship. Int Perspect Sex Reprod Health. 2011;37(2):58-66.

15. Curtis SL. Contraceptive use dynamics research needs post fertility transition. Rev Bras Estud Popul. 2012;29(1):191-3.

16. Jain AK, Winfrey W. Contribution of contraceptive discontinuation to unintended births in 36 developing countries. Stud Fam Plann. 2017;48(3):269-78.

17. Sedgh G, Singh S, Hussain R. Intended and unintended pregnancies worldwide in 2012 and recent trends. Stud Fam Plann. 2014;45(3):301-14.

18. Ochako R, Mbondo M, Aloo S, Kaimenyi S, Thompson R, Temmerman M, et al. Barriers to modern contraceptive methods uptake among young women in Kenya: a qualitative study. BMC Public Health. 2015;151:118.

19. Safari W, Urassa M, Mtenga B, Changalucha $\mathrm{J}$, Beard J, Church K, et al. Contraceptive use and discontinuation among women in rural North-West Tanzania. Contracept Reprod Med. 2019;4:18.

20. Arifuddin M, Sarake M, Rahma. Faktor yang berhubungan dengan pemilihan kontrasepsi hormonal pasutri di wilayah kerja Puskesmas Lampa Kecamatan Duampanua Kabupaten Pinrang 2013 [undergraduate thesis]. Makassar: Universitas Hasanuddin; 2013 [cited 2019 October 1]. Available from: http://digilib.unhas.ac.id/opac/detailopac?id=1759.

21. Bakibinga P, Matanda DJ, Ayiko R, Rujumba $\mathrm{J}$, Muiruri C, Amendah D, et al. Pregnancy history and current use of contraception among women of reproductive age in Burundi, Kenya, Rwanda, Tanzania and Uganda: analysis of demographic and health survey data. BMJ Open. 2016;6(3):e009991.

22. Huda FA, Robertson Y, Chowdhuri S, Sarker BK, Reichenbach L, Somrongthong R. Contraceptive practices among married women of reproductive age in Bangladesh: a review of the evidence. Reprod Health. 2017;14(1):69.

23. Khalil NA, Elshazly HM, Tolba E. Family planning counseling sessions at primary health care facilities in Sadat city, Egypt. Int J Med Sci Public Health. 2017;6(6):1106-11.

24. Osei IF, Mayhew SH, Biekro L, Collumbien M, ECAF Team. Fertility decisions and contraceptive use at different stages of relationships windows of risk among men and women in Accra. Int Perspect Sex Reprod Health. 2014;40(3):135-43.

25. Thobani R, Jessani S, Azam I, Reza S, Sami $\mathrm{N}$, Rozi S, et al. Factors associated with the discontinuation of modern methods of contraception in the low income areas of Sukh Initiative Karachi: a communitybased case control study. PLoS One. 2019;14(7):e0218952.

26. Belete N, Zemene A, Hagos H, Yekoye A. Prevalence and factors associated with modern contraceptive discontinuation among reproductive age group women, a community based cross-sectional study in Humera town, northern Ethiopia. BMC Womens Health. 2018;18(1):190.

27. Cavallaro FL, Benova L, Owolabi OO, Ali M. A systematic review of the effectiveness of counselling strategies for modern contraceptive methods: what works and what doesn't? BMJ Sex Reprod Heal. 2020;46(4):254-69.

28. Wahyuni KS, Mahanani S. Efektifitas penggunaan ABPK terhadap capaian pelayanan KB MKJP oleh bidan. Pros Sem Nas Unriyo. 2019;1(2):94-100.

29. Wang W, Mallick L. Understanding the relationship between family planning method choices and modern contraceptive use: an analysis of geographically linked population and health facilities data in Haiti. BMJ Glob Health. 2019;4(Suppl 5):e000765.

30. Rogers D. The impact of mass mediadelivered family planning campaigns in 
developing countries: a meta-analysis [dissertation]. Storrs, USA: University of Connecticut Graduate School; 2018 [cited 2020 February 11]. Available from: https:// opencommons.uconn.edu/cgi/viewcontent. cgi? article $=8220 \&$ context $=$ dissertations .

31. Krenn S, Cobb L, Babalola S, Odeku $\mathrm{M}$, Kusemiju B. Using behavior change communication to lead a comprehensive family planning program: the Nigerian Urban Reproductive Health Initiative. Glob
Health Sci Pract. 2014;2(4):427-43.

32. Myslín M, Zhu SH, Chapman W, Conway M. Using twitter to examine smoking behavior and perceptions of emerging tobacco products. $\mathrm{J}$ Med Internet Res. 2013;15(8): 174 .

33. Laksono AD, Wulandari RD. Analisis potensi penyebaran informasi kesehatan melalui jejaring sosial (studi kasus pada 'Forum Jejaring Peduli AIDS'). Bul Penel Sistem Kes. 2011;14(4):358-65. 